\title{
TREATMENT OF HIGH-STRENGTH AMMONIA CONTAINING WASTEWATER USING PARTIAL NITRITATION SYSTEM WITH BIOLOGICAL SELECTOR
}

\author{
JIN Y. ${ }^{1}$ \\ WANG D. ${ }^{2,3}$ \\ ZHANG W. ${ }^{2,3}{ }^{*}$
}

\author{
${ }^{1}$ Guangxi Key Laboratory of New Energy and Building Energy Saving \\ College of Civil Engineering and Architecture \\ Guilin University of Technology, 12, Jiangan Road, Guilin \\ 541004, P.R. China \\ ${ }^{2}$ Guangxi Key Laboratory of Environmental Pollution \\ Control Theory and Technology \\ Guilin University of Technology, Guilin, 541004, P.R. China \\ ${ }^{3}$ Guangxi Collaborative Innovation Center for Water Pollution Control \\ and Water Safety in Karst Area \\ Guilin University of Technology, Guilin, 541004, P.R. China
}

Received: 22/08/2015

Accepted: 01/10/2015

Available online: 14/10/2015 *to whom all correspondence should be addressed: e-mail: 2010053@glut.edu.cn

\section{ABSTRACT}

In this paper, one partial nitritation system with biological selector (PNBS) was first evaluated in treating high-strength ammonia containing wastewater. Nitrite production rate (NPR) of $8.25 \mathrm{~kg} \mathrm{~N} \mathrm{~m}^{-3} \mathrm{~d}^{-1}$ was achieved with influent $\mathrm{NH}_{4}-\mathrm{N}$ concentration $2000 \mathrm{mg} \mathrm{l}^{-1}$ and HRT $3.2 \mathrm{~h}$, which is, to our knowledge, the highest NPR to be treated successfully by an nitritation reactor. A genetic analysis of the organisms in the PNBS revealed an abundance of Nitrosomonas sp. ENI-11, uncultured bacterium clone: AnDHS-3, Nitrosomonas sp. ENI-11 and Nitrosomonas eutropha enriched in the PNBS reactor.

Keywords: Nitritation; Biological selector; High-strength; Ammonia containing wastewater; Nitrite oxidizing bacteria;

\section{Introduction}

ANaerobic AMMonium OXidation (ANAMMOX) process has proven to be one promising technology due to high efficiency, low running cost and reasonable footprint comparing to conventional biological nitrogen removal process (Kuenen, 2008). The number of full-scale installations has substantially increased in the past three to five years since the first full-scale partial nitrification-anammox reactor in Rotterdam (Van der Star et al., 2007). In order to achieve nitrogen removal, about 56\% ammonia in the wastewater should only be oxidized to nitrite by ammonia oxidizing bacteria (AOB) in an anammox process. Following, anammox bacteria convert nitrite and residual ammonia into nitrogen gas under anerobic contions. However, nitrite oxidizing bacteria (NOB), mutualistic bacteria of AOB, can oxidize nitrite to nitrate, which cannot be degraded any further by anammox process. Therefore, the growth and activity of NOB should be strictly controlled in anammox process.

High temperature, low dissolved oxygen (DO), and free ammonia are usually suggested to inhibit the growth of NOB (Fux et al., 2002). SHARON (Single reactor system for High activity Ammonium Removal Over Nitrite) process has been developed in view of different growth rate of AOB and NOB under high temperature, and reasonable sludge retention time (SRT) is controlled in the reactor (Hellinga et al., 
1998). Subsequently, although high nitrogen loading rate up (NLR) to $10 \mathrm{~kg} \mathrm{~m}^{-3} \mathrm{~d}^{-1}$ was reported in one full-scale anammox reactor, NLR was only achieved at $0.8 \mathrm{~kg} \mathrm{~m}^{-3} \mathrm{~d}^{-1}$ in the nitritation reactor due to the short SRT (Van der Star et al., 2007). In some cases, low DO was adopted to inhibit the growth and activity of NOB (Sun et al., 2014). However, low DO decreases the matrix transfer rate of AOB, which is the key factor for high rate wastewater treatment. It was reported that the growth of NOB would be limited when free ammonia reached 0.1-10 $\mathrm{mg} \mathrm{l}^{-1}$ in the reactor (Jianlong and Ning, 2004). Thus, $\mathrm{pH}$ adjustment was used to control the free ammonia in the reactor (Qiao et al., 2008). Nonetheless, NOB could accustome to high free ammonia condition following the cultivation period, therefore, combined method such as low DO is also adopted in real wastewater treatment. As a result, reducing NLR is often adopted for anammox process. In order to reduce the footprint of anammox process, increasing NLR was urgent for nitritation reactor.

In this study, one new designed partial nitritation system with biological selector (PNBS) was used to study the maximum nitrogen loading rate for nitritation process. Genetic analysis using the 16S rRNA gene was employed to characterize the microbial population of the bacteria in the reactor.

\section{Materials and methods}

The PNBS system includes aeration zone and biological selector (Fig. 1). The cross-sectional areas of the aeration zone were $25 \times 20 \mathrm{~cm}$, and the height of effluent port was $100 \mathrm{~cm}$ (total volume $50 \mathrm{I}$ ). A biological selector with volume of $10 \mathrm{I}$ was used for $\mathrm{AOB}$ selecting and recycling. DO under $0.5 \mathrm{mg} \mathrm{l}^{-1}$ was controlled to inhibit the growth of NOB in the biological selector, and recycling rate of $400 \%$ was adopted to select the sludge of aeration zone. One mixer was set on the upper part of the biological selector, which was used for agitating the settling sludge. The feed solution was introduced to the updraft section with a peristaltic pump (Baoding Longer Precision Pump ZG-600). Air was supplied using an air pump at the bottom. $\mathrm{pH}$ was controlled by addition of alkali $\left(0.5 \mathrm{~mol} \mathrm{I}^{-1} \mathrm{NaHCO}_{3}\right.$ and $\left.0.5 \mathrm{~mol} \mathrm{I}^{-1} \mathrm{Na}_{2} \mathrm{CO}_{3}\right)$ solution. Reactor temperature was controlled by using one heater.

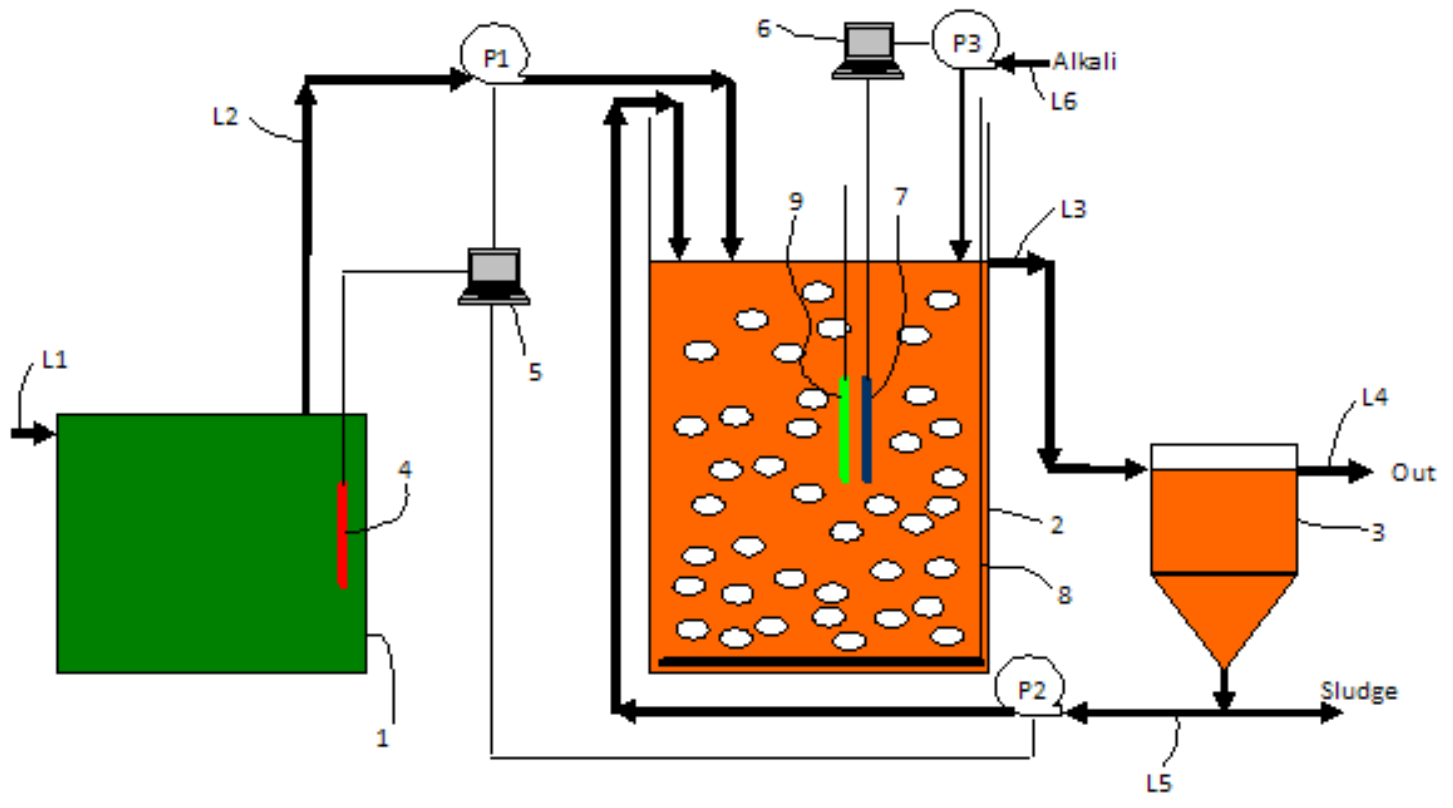

Figure 1. Schematic view of PNBS system

(Symbols: L1 Influent; L2 Influent pipe; L3 Aeration zone out-pipe; L4 Effluent pipe; L5 Sludge-recycle pipe; L6 Alkali pipe; 1 Adjustment tank; 2 Aeration zone; 3 Biological selector; 4 Ammonia online analyzer; 5 Pump flow controlling panel; 6 Alkali pump flow controlling panel; 7 pH online analyzer; 8 Air blow; 9 DO online analyzer; P1 Influent pump; P2 Sludge-recycle pump; P3 Alkali pump) 
The PNBS system was inoculated with activated sludge from a running ceramic membrane reactor in Guilin, China, and the initial mixed-liquor suspended solids (MLSS) concentration was $2000 \mathrm{mg} \mathrm{l}^{-1}$. The reactor was fed with synthetic wastewater. Nutrient medium consisted of 500-2000 mg- $\mathrm{N} \mathrm{I}^{-1} \mathrm{NH}_{4} \mathrm{HCO}_{3}$, $50 \mathrm{mg} \mathrm{l}^{-1} \mathrm{KH}_{2} \mathrm{PO}_{4}, 200 \mathrm{mg} \mathrm{l}^{-1} \mathrm{MgSO}_{4} \cdot 2 \mathrm{H}_{2} \mathrm{O}, 300 \mathrm{mg} \mathrm{l}^{-1} \mathrm{CaCl}_{2} \cdot 2 \mathrm{H}_{2} \mathrm{O}$, and $1 \mathrm{ml}$ of trace element solution I and II (Qiao et al., 2008).

$\mathrm{NO}_{2}-\mathrm{N}$ was measured by the colorimetric method according to Standard Methods (APHA, 1995). $\mathrm{NH}_{4}-\mathrm{N}$ was measured by the phenate method according to Kanda (1995). Total nitrogen (TN) was determined by the persulfate method (APHA, 1995) using the UV spectrophotometric screening method (APHA, 1995) for quantification of $\mathrm{TN}$ as $\mathrm{NO}_{3}-\mathrm{N}$ (the oxidization product of the persulfate digestion). $\mathrm{NO}_{3}-\mathrm{N}$ (of the original sample) was determined by calculation of the difference of TN and the sum of $\mathrm{NO}_{2}-\mathrm{N}$ and $\mathrm{NH}_{4}-\mathrm{N}$. The $\mathrm{pH}$ was measured by using a $\mathrm{pH}$ meter (9010, Jenco, USA), and dissolved oxygen (DO) was measured by using a DO meter (6010, Jenco, USA).

During the operation, the sludge was taken out from the PNBS reactor. The sludge samples were first ground with a pestle under liquid nitrogen.

\subsection{DNA extraction and PCR amplification}

Meta-genomic DNA was extracted using an ISOIL kit (Wako, Osaka, Japan) according to the manufacturer's instructions. Amplification of the 16S rRNA gene was performed with Phusion High-Fidelity DNA polymerase (FINNZYMES, Finland) using conserved eubacterial primers 6F (forward primer: 5'-GGAGAGTTAGATCTTGGCTCAG-3') and 1492r (reverse primer: 5'-GGTTACCTTGTTACGACT-3'). PCR was carried out according to the following thermocycling parameters: $30 \mathrm{~s}$ initial denaturation at $98{ }^{\circ} \mathrm{C}, 25$ cycles of $10 \mathrm{~s}$ at $98^{\circ} \mathrm{C}, 30 \mathrm{~s}$ at $51{ }^{\circ} \mathrm{C}, 20 \mathrm{~s}$ at $72^{\circ} \mathrm{C}$ and $5 \mathrm{~min}$ final elongation at $72{ }^{\circ} \mathrm{C}$. The amplified products were electrophoresed on a $1 \%$ agarose gel and extracted fragments were purified using Wizard SV Gel and PCR Clean-Up System (Promega, U.S.A.).

\subsection{Cloning and sequencing of the 165 rRNA gene}

The purified fragments wereligated into the EcoRV site of pBluescript II KS+ (Stratagene, USA) and Escherichia coli DH10B was transformed using the constructed plasmids. White colonies including the insert were randomly chosen and the plasmids were extracted by the alkaline method. The nucleotide sequences were determined with a 3130xl genetic analyzer and a BigDye terminator v3.1 cycle sequencing kit (Applied Biosystems, USA). The sequences determined in this study were compared with the sequences in the nrdatabase using the basic local alignment search tool program (BLAST) on the NCBI web site.

\subsection{Denaturing gradient gel electrophoresis (DGGE)}

Partial 16S rRNA gene was amplified by PCR with a eubacterial primer set, 1055F-1392R.

The extracted meta-genomic DNA and cloned plasmids were used as templates for the sample and markers in the DGGE, respectively. The amplified fragments were purified and combined with the GCclamp (5'-CGCCCGCCGCGCCCCGCGCCCGTCCCGCCGCCCCCGCCCG-3') at the 5' termini by a second PCR using a primer set, $357 \mathrm{~F}$ with GC-clamp and 534R. The products were resolved by DGGE for $14 \mathrm{~h}$ at $90 \mathrm{~V}$ at $60{ }^{\circ} \mathrm{C}$ using the DCode system (Bio-Rad, Hercules, CA, U.S.A.). An 8\% polyacrylamide gel with a 30-65\% denaturing gradient was used, where $100 \%$ denaturant was defined as 7 Murea and $40 \%$ formamide. The gel was stained with SYBR-Gold (Invitrogen, U.S.A.) and visualized using the FLA-2000 system (Fuji Photo Film, Tokyo, Japan).

\section{Results}

A nitrogen loading rate (NLR) of $0.8 \mathrm{~kg} \mathrm{~N} \mathrm{~m}^{-3} \mathrm{~d}^{-1}$ was used at the startup of the PNBS reactor, followed by gradual increases in the loading as the AOB population was enriched. The time courses of the levels of nitrogenous compounds over the course of the study are shown in Fig. 2. In this study, an effluent $\mathrm{NO}_{2}-\mathrm{N}$ to $\mathrm{NH}_{4}-\mathrm{N}$ above 1.32 was considered as the achievable goal for the start-up of the PNBS reactor in order to provide appropriate substrate for the following anammox reactor (Mulder et al., 1995). 
The start-up period for the PNBS reactor was considered to be from day 0 to day 5 (Fig. 2), during which time the influent $\mathrm{NH}_{4}-\mathrm{N}\left(500 \mathrm{mg} \mathrm{l}^{-1}\right)$ and HRT (15 h) was remained constant. The corresponding effluent $\mathrm{NO}_{2}-\mathrm{N}$ to $\mathrm{NH}_{4}-\mathrm{N}$ achieved on day 5 was 4.1 corresponding to zero $\mathrm{NO}_{3}-\mathrm{N}$ production. Subsequently, from day 6 to day 108 (Fig. 2), NLR was increased stepwise to $1.2 \mathrm{~kg} \mathrm{~N} \mathrm{~m}^{-3} \mathrm{~d}^{-1}, 1.7 \mathrm{~kg} \mathrm{~N} \mathrm{~m}^{-3} \mathrm{~d}^{-1}, 2.1 \mathrm{~kg} \mathrm{~N} \mathrm{~m}^{-3} \mathrm{~d}^{-1}$, $3.3 \mathrm{~kg} \mathrm{~N} \mathrm{~m}^{-3} \mathrm{~d}^{-1}, 5.0 \mathrm{~kg} \mathrm{~N} \mathrm{~m}^{-3} \mathrm{~d}^{-1}, 7.5 \mathrm{~kg} \mathrm{~N} \mathrm{~m}^{-3} \mathrm{~d}^{-1}, 10 \mathrm{~kg} \mathrm{~N} \mathrm{~m}^{-3} \mathrm{~d}^{-1}$ and $15 \mathrm{~kg} \mathrm{~N} \mathrm{~m}^{-3} \mathrm{~d}^{-1}$ to probe the treatment potential of the PNBS reactor. On day 95, the influent $\mathrm{NH}_{4}-\mathrm{N}$ concentration and NLR was increased to $2000 \mathrm{mg} \mathrm{l}^{-1}$ and $15 \mathrm{~kg} \mathrm{~N} \mathrm{~m}^{-3} \mathrm{~d}^{-1}$, respectively, which were the highest levels in this study. Under these conditions, the effluent $\mathrm{NO}_{2}-\mathrm{N}$ and $\mathrm{NH}_{4}-\mathrm{N}$ concentrations were $1100 \mathrm{mg} \mathrm{l}^{-1}$ and $830 \mathrm{mg} \mathrm{l}^{-1}$, respectively. Overall, the reactor could operate with a stable effluent $\mathrm{NO}_{2}-\mathrm{N}$ to $\mathrm{NH}_{4}-\mathrm{N}$ of over 1.32 .

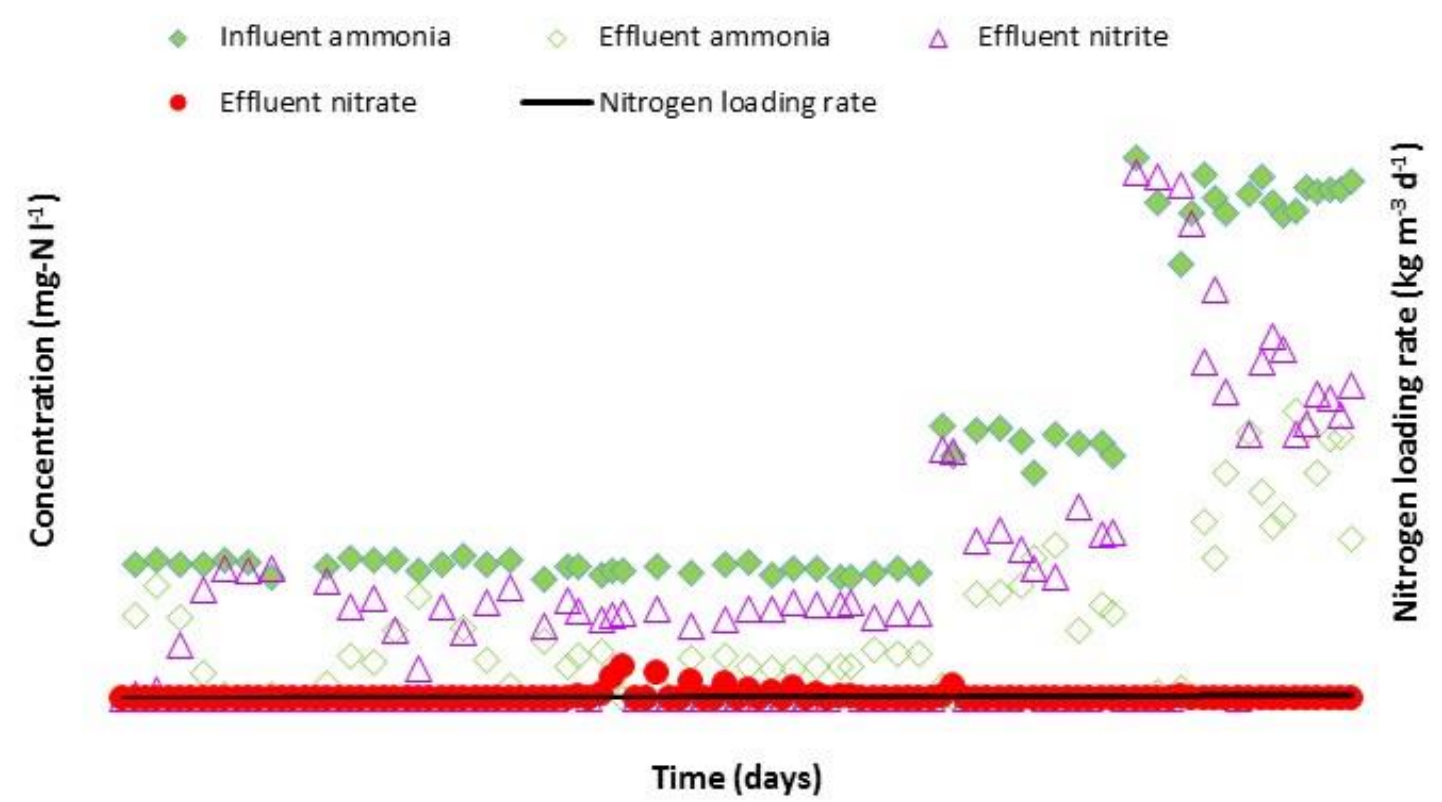

Figure 2. Reactor performance during the study

Table 1. Homology search results for $16 \mathrm{~S}$ rRNA gene sequences of the main bacterial members in the community

\begin{tabular}{|c|c|c|c|c|c|c|c|c|}
\hline \multirow[b]{2}{*}{ Phylum } & \multirow[b]{2}{*}{ Taxon } & \multirow[b]{2}{*}{$\begin{array}{l}\text { Identity } \\
(\%)\end{array}$} & \multicolumn{6}{|c|}{ Number of clones } \\
\hline & & & $\begin{array}{c}\text { Day } \\
0\end{array}$ & $\begin{array}{l}\text { Day } \\
20\end{array}$ & $\begin{array}{l}\text { Day } \\
40\end{array}$ & $\begin{array}{l}\text { Day } \\
60\end{array}$ & $\begin{array}{l}\text { Day } \\
80\end{array}$ & $\begin{array}{l}\text { Day } \\
108\end{array}$ \\
\hline \multirow{4}{*}{ 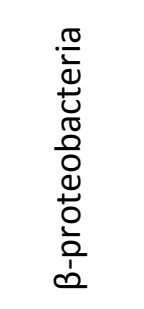 } & Nitrosomonas sp. ENI-11 & $98-100$ & 3 & 12 & 15 & 25 & 30 & 32 \\
\hline & $\begin{array}{l}\text { Uncultured bacterium clone: } \\
\text { AnDHS-3 }\end{array}$ & 100 & 1 & 1 & 1 & 2 & 2 & 2 \\
\hline & Nitrosomonas sp. ENI-11 & 95 & 1 & 1 & 1 & 1 & 1 & 1 \\
\hline & Nitrosomonas eutropha & 98 & 1 & 1 & 1 & 1 & 1 & 1 \\
\hline \multirow{4}{*}{ 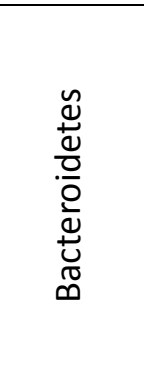 } & $\begin{array}{c}\text { Uncultured soil bacterium } \\
\text { clone bacnit28 }\end{array}$ & 96 & 10 & 8 & 8 & 6 & 6 & 4 \\
\hline & $\begin{array}{l}\text { Uncultured bacterium clone } \\
\text { DSBR-B022 }\end{array}$ & 99 & 22 & 15 & 12 & 5 & 3 & 1 \\
\hline & $\begin{array}{l}\text { Uncultured bacterium clone } \\
\text { KD3-77 }\end{array}$ & 91 & 10 & 6 & 4 & 5 & 2 & 1 \\
\hline & $\begin{array}{l}\text { Uncultured bacterium clone } \\
\text { NR.4.002 }\end{array}$ & 90 & 2 & 1 & 1 & 1 & 1 & 1 \\
\hline
\end{tabular}


In this study, the seed sludge used in the PNBS reactor was drawn from a running MBR reactor. Samples were collected on day 0 , day 20, day 40, day 60, day 80 and day 108 (Table 1 ). The genetic analysis showed that the share of Nitrosomonas. increased from $12 \%$ to $83.72 \%$ at the genus level. Nitrosomonas sp. ENI11, Uncultured bacterium clone: AnDHS-3, Nitrosomonas sp. ENI-11 and Nitrosomonas eutropha was dominant in the PNBS reactor. Uncultured soil bacterium clone bacnit28, Uncultured bacterium clone DSBR-B022, Uncultured bacterium clone KD3-77 and Uncultured bacterium clone NR.4.002, were identified as co-existing bacteria in the PNBS reactor. Although these bacteria were also reported by other researchers (Yamamoto et al., 2006), their functions are largely unknown.

\section{Discussions}

As shown in Fig. 2, the influent $\mathrm{NH}_{4}-\mathrm{N}$ concentration was increased to $2000 \mathrm{mg} \mathrm{l}^{-1}$ with NLR at $15 \mathrm{~kg} \mathrm{~N} \mathrm{~m}^{-3} \mathrm{~d}^{-1}$ (process hydraulic retention time of $3.2 \mathrm{~h}$ ) near the end of the study. To our knowledge, this is the highest influent $\mathrm{NH}_{4}-\mathrm{N}$ concentration to be successfully treated to date (Table 2). Highly concentrated nitrogen wastewater is usually diluted prior to treatment in nitritation reactor (Yamamoto et al., 2011). However, this practice is forbidden by law for wastewater treatment in China. Accordingly, the PNBS reactor as demonstrated here could have a very effective application for naturally occurring high-strength wastewaters.

Table 2. Comparison of possible influent $\mathrm{NH}_{4}-\mathrm{N}$ concentration and NLR for different reactors in wastewater treatment

\begin{tabular}{lcccc}
\hline \multicolumn{1}{c}{ Reactor type } & $\begin{array}{c}\text { Reactor } \\
\text { volume }(\mathrm{I})\end{array}$ & $\begin{array}{c}\mathrm{NLR} \\
\left(\mathrm{kg} \mathrm{m}^{-3} \mathrm{~d}^{-1}\right)\end{array}$ & $\begin{array}{c}\text { Influent } \mathrm{NH}_{4}-\mathrm{N} \\
\text { concentration } \\
\left(\mathrm{mg} \mathrm{l}^{-1}\right)\end{array}$ & References \\
\hline $\begin{array}{l}\text { Continuous activated } \\
\text { sludge system }\end{array}$ & 25 & 9.3 & 1400 & Torà et al. (2014) \\
\hline $\begin{array}{l}\text { Granular airlift reactor } \\
\text { Internal-loop airlift } \\
\text { reactor }\end{array}$ & 150 & 1.75 & 700 & Torà et al. (2013) \\
\hline PNBS & 3.8 & 1.58 & 1484 & Xing et al. (2013) \\
\hline
\end{tabular}

The predominant bacteria in this study are Nitrosomonas sp. ENI-11, Uncultured bacterium clone: AnDHS3, Nitrosomonas sp. ENI-11 and Nitrosomonas eutropha, which is a population balance same as others cases (Yamamoto et al., 2006). Yamamoto et al., (2011) reported that only 15\% of the total clones were identified as Nitrosomonas in one nitritation reactor. In this study, Nitrosomonas was enriched at $83.72 \%$. Accordingly, the achieved NLR is near to 7 times of the NLR reported by Yamamoto et al., (2011). Thus, it is considered that the PNBS reactor used in this study can enrich Nitrosomonas effectively by which the NLR can be readily increased. Above that, PNBS reactor can provide appropriate conditions for Nitrosomonas, therefore, high NLR might be achieved by enhancing the activity of Nitrosomonas.

\section{Conclusions}

One PNBS reactor was used to investigate the treatment potential of ammonia containing wastewater. $\mathrm{NLR}$ was increased stepwise to $15 \mathrm{~kg} \mathrm{~N} \mathrm{~m}^{-3} \mathrm{~d}^{-1}$ with the influent $\mathrm{NH}_{4}-\mathrm{N}$ concentration of $2000 \mathrm{mg} \mathrm{l}^{-1}$. The effluent $\mathrm{NO}_{2}-\mathrm{N}$ and $\mathrm{NH}_{4}-\mathrm{N}$ concentrations were $1100 \mathrm{mg} \mathrm{l}^{-1}$ and $830 \mathrm{mg} \mathrm{l}^{-1}$, respectively. The reactor could operate with a stable effluent $\mathrm{NO}_{2}-\mathrm{N}$ to $\mathrm{NH}_{4}-\mathrm{N}$ of over 1.32. The results got in this study suggested that PNBS reactor can enrich and provide appropriate conditions for Nitrosomonas.

\section{Acknowledgements}

This research was supported by the National Natural Science Foundation of China (51108108), Guangxi Natural Science Foundation (2013GXNSFCA019018; 2014 GXNSFBA118265), Research Projects of the Education Department 
of Guangxi Government (2013ZD031; 2013ZL076; ZL2014051; KY2015ZL118), Guangxi Key Laboratory of New Energy and Building Energy Saving (12-J-21-2), Guangxi Scientific Experiment Center of Mining, Metallurgy and Environment, the Project of High Level Innovation Team and Outstanding Scholar in Guangxi Colleges and Universities.

\section{References}

APHA (1995), Standard method for the examination of water and wastewater, 19th ed. American Public Health Association, Washington, D.C.

Feng Q., Wang Y., Wang T., Zheng H., Chu L., Zhang C., Chen H., Kong X. and Xing X. (2012), Effects of packing rates of cubic-shaped polyurethane foam carriers on the microbial community and the removal of organics and nitrogen in moving bed biofilm reactors, Biores. Technol., 117, 201-207.

Fux C., Boehler M., Huber P., Brunner I. and Siegrist H. (2002), Biological treatment of ammonium-rich wastewater by partial nitritation and subsequent anaerobic ammonium oxidation (anammox) in a pilot plant, J. Biotechnol., 99, 295-306.

Hellinga C., Schellen A.A.J.C., Mulder J.W., Van Loosdrecht M.C.M. and Heijnen J.J. (1998), The SHARON process: an innovative method for nitrogen removal from ammonium-rich waste water, Water Sci. Technol., 37, 135-142.

Jianlong W. and Ning Y. (2004), Partial nitritation under limited dissolved oxygen conditions, Process. Biochem., 39, 1223-1229.

Kanda J. (1995), Determination of ammonium in seawater based on the indophenol reaction with o-Phenylphenol (OPP), Wat. Res., 29, 2746-2750.

Kuenen J.G. (2008), Anammox bacteria: from discovery to application, Nat. Rev. Microbiol., 6, 320-326.

Mulder A., Van de Graaf A.A., Robertson L.A. and Kuenen J.G. (1995), Anaerobic ammonium oxidation discovered in a denitrifying fluidized bed reactor, FEMS Microbiol. Ecology, 16, 177-184.

Qiao S., Kawakubo Y., Koyama T. and Furukawa K. (2008), Partial nitritation of raw anaerobic sludge digester liquor by swim-bed and swim-bed activated sludge processes and comparison of their sludge characteristics, J. Biosci. Bioeng., 106, 433-441.

Sun F., Sun B., Li Q., Deng X., Hu J. and Wu W. (2014), Pilot-scale nitrogen removal from leachate by ex situ nitritation and in situ denitritation in a landfill bioreactor, Chemosphere, 101, 77-85.

Torà J.A., Lafuente J., Garcia-Belinchón C., Bouchy L., Carrera J. and Baeza J.A. (2014), High-throughput nitritation of reject water with a novel ammonium control loop: Stable effluent generation for anammox or heterotrophic denitritation, Chem. Eng. J., 243, 265-271.

Torà J.A., Moliné E., Carrera J. and Pérez J. (2013), Efficient and automated start-up of a pilot reactor for nitritation of reject water: From batch granulation to high rate continuous operation, Chem. Eng. J., 226, 319-325.

Van der Star W.R., Abma W.R., Blommers D. Mulder J.W. Tokutomi T., Strous M., Picioreanu C. and Van Loosdrecht M. (2007), Startup of reactors for anoxic ammonium oxidation: experiences from the first full-scale anammox reactor in Rotterdam, Wat. Res., 41, 4149-4163.

Xing B.S., Ji Y.X., Yang G.F., Chen H., Ni W.M. and Jin R.C. (2013), Start-up and stable operation of partial nitritation prior to ANAMMOX in an internal-loop airlift reactor, Sep. Purif. Technol., 120, 458-466.

Yamamoto T., Takaki K., Koyama T. and Furukawa K. (2006), Novel partial nitritation treatment for anaerobic digestion liquor of swine wastewater using swim-bed technology, J. Biosci. Bioeng., 102, 497-503.

Yamamoto T., Wakamatsu S., Qiao S., Hira D., Fujii T. and Furukawa K. (2011), Partial nitritation and Anammox of a livestock manure digester liquor and analysis of its microbial community, Biores. Technol., 102, 2342-2347. 